\title{
Discursive Construction of Power Relations in Pashtun Society in Hamid Khan's Short Story Badmash
}

\author{
* Muhammad Ramzan, MPhil (English Linguistics) \\ ** Dr. Abdul Karim Khan, Assistant Professor (Corresponding Author)
}

\begin{abstract}
This paper deals with the critical exploration of Power in the Pashtun society depicted in Hamid Khan's Badmash. The story was published in The Journal of the English Literary Club Department of English, University of Peshawar, Pakistan, and session 1982-1983. The story portrays the realistic picture of the Pashtun society where there is the rule of the powerful. Those who commit crimes and murders can grab every lucrative opportunity. They get very influential. This badly affects the younger generation as they are negatively influenced. Hamid Khan has a critical eye on the evils prevailed in the society. The researchers used Critical Discourse Analysis (CDA) as the tool for critical investigation of the selected lines, passages, or excerpts which contain power exercise in every shape such as power through language, wealth, or through bodily strength. In this regard, Fairclough's (1989) Three Dimensional Model (TDM) of CDA has been adopted for the analysis of the text.
\end{abstract}

Keywords: Badmash, Hamid Khan, Discourse, Critical Discourse Analysis, TDM, Power Introduction

This research paper is the critical assessment of Hamid Khan's short story Badmash (1982) in which the author of the text discursively portrayed the Pashtun society where power is the basic option for one's existence. The story Badmash gives us the message that the young ones of the society are being encouraged by the bad company to committing crimes. Pashtun society experiences many domestic problems caused by poverty, drug addiction, and other evils. Another big problem of society is the use of power in an abusive way. Power is the main source for dominating innocent humanity and controlling the resources of the state.

It is the story of two young boys Aman, ten years old, and Gul, eight years old. They live miserable lives as their mothers are badly treated by their fathers who are not good men of society. Aman's father is a drug addict that leads him to peevishness and penniless. Consequently, the mother is being beaten by the father who destroys the child's personality. Gul wishes to become a Badmash (notorious and rogue) of society. He thinks that in this way he will control everything. He is turned by the circumstances into a cruel being who does not pity the little puppy while beating it. Aman's father is a gambler too. Aman is scattered into pieces internally when Gul tells him that his father once stabbed a man to death. The story gives us the message that the young ones of the society are being encouraged by the bad company to committing crimes. Our society experiences many domestic problems caused by poverty, drug addiction, and other evils.

\section{The Author}

Hamid Khan is a local poet who writes poetry and short stories in English. He has published two volumes of poetry i.e. Three Voices and Velvet of Loss (2002), and also published more than six short stories in various dailies and the Journal of English Literary Club, Department of English, University of Peshawar. The poetic collection the Three Voices is a collaborated work with Professor Daud Kamal and Kaja Ikram Azam.

Apart from his literary pursuits, Hamid Khan did his Ph.D. in English and successfully supervised many scholars at M.Phil and Ph.D. levels. He also worked at various administrative positions and retired as a bureaucrat. Currently, he is working as Chairman of the Department of

* Qurtuba University DI Khan Email: ramzannurar@gmail.com

** Department of English and Applied Linguistics UST, Bannu Email: akarim.khan@ yahoo.com 
English Linguistics and Literature Qurtuba University of Science and Information Technology, Peshawar.

\section{Discourse}

A systematically investigated communication or speech patterns, the use of language and its structure can be termed as discourse. Discourse is known as the renovation of language into a social context. Parker (1992) defines discourse as the compilation of well-arranged as well as meaningful text. Discourse is the biggest component of the use of language where dominance and power play a major role. Halliday (1978) defines discourse as the mutual involvement of people in grammatical or linguistic interaction, written/spoken in a functional milieu as the words given in the dictionary.

Again, Brown (1994) puts that traditionally, text (discourse) was interpreted and analyzed through the text producer's intentions, his historical milieu, and philosophy about life, but in the modern era, the act of interpretation has nothing to do with the author's intention and historical background or his life philosophy. He says that the text should be analyzed through the analyst's own opinion and objectively rather than to deal with the author's mental and environmental situations and personality.

According to Fairclough (1989), discourse can be defined through structural as well as functional ways. He considers discourse as a type of a "social process" (p. 22). Fairclough and Wodak (1997) assert that discourse cannot be separated from society as it is an essential part of society. Anderson and Gerbing (1988) say that the originators of structuralism are mainly concerned with the variety of the language and deem language as an individual or personal property while the proponents of formalism are concerned with the content e.g. language use.

\section{Literature Review}

Hamid Khan lives in an era when Diaspora, identity, and hybridity have been the most prominent themes among the post-colonial writers. In this connection, Hajiyeva (2016) in her Pakistani English Literature in Multicultural Context states that Pakistani literature in English encompasses the idea of multi-culturalism and the possibility of living with harmony on part of the people experiencing diverse cultures and maintaining their inherited way of life. She adds that this sometimes leads to a hybrid identity. Hamid Khan's case is somehow different. Leaving aside the popular themes of postcolonial literature, Khan is content to take into consideration the local issues and problems faced by the people on account of poverty and illiteracy on one hand, and narrow-mindedness hypocrisy on the other. His heart is filled with pity for the downtrodden and forsaken of society.

Khan (2020) says that Tariq Rahman's epoch-making effort of writing A History of Pakistani Literature in English published in 1990 paved the way for scholars for taking interest in Pakistani literature in English. He asserts that this book covers all the literary creation which are written by Pakistani writers both indoor and outside of Pakistan. The book has spent all the attention on poetry but it also presents a list of novels as well as dramas written by Pakistani writers. Awan and Yahya (n.d.) analyzed Ahmad Ali's Twilight in Delhi through the perspective of CDA using Fairclough's TDM. They have cited Cook (1990) in supporting their use of CDA as a suitable tool for the analysis of any kind of literary texts such as novels, short stories, and short conversations as well, and that all these texts should be taken as Discourse.

Khan and Zahir Jang (Jan-March, 2020) assert about the poetic style of Hamid Khan's use of stenographic and terse style in his poems. They further assert that Hamid Khan has left the sentences incomplete in his poetry while filling that gaps through using foreign words as code switched that coerces readers to think over the relationship of these foreign words or code-switching words with the actual-world issues. Talking about the deviation in the shape of code-switching, they assert that Hamid Khan uses different tools such as deviant punctuation marks, unusual syntax as well as graphological effects.

\section{Methodology}

The objective of the current study is to explore the hidden ideology and meaning of the text (discourse). The story understudy discursively represented the main issues faced by the Pashtun society. The main issues depicted in the story are the exercise of power, exploitation, crimes, and murders for nothing but to rub and to show oneself as Badmash (Rogue). The researcher uses Fairclough's (1989) approach of Critical Discourse Analysis as a theory whiles his Three Dimensional Model (TDM) as the framework for analyzing the selected text (discourse). 
Critical Discourse Analysis (CDA) is the only tool to extract the veiled meaning from the text of the story. As the story narrates some basic issues in society that can be best analyzed through the lens of CDA. The role of CDA is to deal with the investigation of all those problems which are concerned with power relations, power exercise, and dominance. Van Dijk (1998) also says the same in pointing out the aims of CDA. He says that Critical Discourse Analysis is concerned with examining spoken/written discourse (text) to explore the main discursive means of power, dominance as well as inequality in a society.

In the case of Fairclough, CDA is meant to address issues faced by society. He brings forth two assumptions about the use of language that are: language is (a) socially shaped and (b) socially shaping. Mirzaee and Hamidi (2012) quoted Fairclough that "Language use is always simultaneously constitutive of social identities, social relations and systems of knowledge and belief" (p.188). Fairclough (1989) names his approach to CDA as a Critical Language Study (CLS). He further elaborates the notion 'Critical' as it stands for to unfold the meaning which is hidden in the text under critical examination.

\section{Fairclough's Three Dimensional Model (TDM)}

Fairclough's (1989) Three Dimensional Model is a suitable tool for the analysis of any literary or nonliterary text (discourse). Fairclough's framework contains ten main questions and sub-questions through which a text can be analyzed. It contains three levels of analysis i.e. Description, Interpretation, and Explanation. The level of description deals with the formal features of the discourse (text), the level of Interpretation is concerned with the relationship of text and interaction while the level of Explanation deals with the social context and interaction. Fairclough (1989) has been divided the ten main questions into three parts. The first part has been given the name Vocabulary, the second part has been named Grammar and the third part has been named Textual Structures (see pages 110-111). All these sections have several questions and have been elaborated with examples (see page 112-139). The present paper is conducted in the light of Fairclough's these ten questions through the above-mentioned questions.

\section{Analysis}

This part of the paper has given us some aspects of the novel and the author himself as well. These aspects have been given under separate headings as below.

\section{Power and Gender Discrimination in Pashtun Society}

Through the study of the story, we can examine power and gender discrimination in every sentence of the text. The producer of the story discursively constructed the main issue discussed in this literary piece. The author of the text himself is the part of the society which he has depicted in the story. That is why; he is successful in depicting the real face of the society shown in this story.

\section{Extract 1}

\section{"1. Mother quarrel with him, but he is strong. 2. He always beat her: and then the} mother is ill. 3. I hate my father, I hate him. 4. It is bad to beat the weak."

(Badmash, p-163).

The extract has been taken from the story under analysis. All the sentences have given numbers for the ease of analysis of each sentence separately. These lines discursively represent dominance, power relations, and superiority of men over women. The passage is a narrative story of a child about his parents who always quarrel when his mother prevents her husband from smoking heroines and gambling.

\section{Description}

This part is concerned with exploring the formal properties of the text through the ten main as well as sub-questions of Faircluogh's (1989) framework. All those questions used for the analysis of the selected text are following the formal features which the selected excerpt has. The text is analyzed under the questions 1, 2, 3, 5, 6, and 8 of Fairclough's (1989, p-110-112) framework.

The conversation is in a narrative mode between two friends (equals) so the use of language is formal. There are four sentences in the extract which are simple declarative sentences that have relational, grammatical, and experiential values. Sentence 1 is a compound one that consists of two clauses that are combined through a logical connector "but". The second sentence is also a compound comprised of two parts which are connected by the conjunction "and", sentence 3 is simple declarative with the repetition of the word "hate" and sentence number 4 is a simple sentence. The ideologically significant vocabulary/words or phrases are the word "strong" in the first sentence, the 
expression "He always beat her" in the second sentence, and the last sentence "It is bad...weak". Nominalizations used in the passage are the words "mother" and "father" in sentences 1 and 3. Pronouns used here, are the objective case pronoun "him" occurred two times in sentences 1 and 3, the third person pronoun "he" occurred two times in the first and second sentences of the passage, the possessive case of the third person pronoun "her" in sentence 2, and the first person pronoun "I" (two occurrences) and the possessive case of first-person pronoun "my" in sentence 3 . These pronouns are used exclusively having their relational values and are restricted to the sole individuals. The demonstrative pronoun "it" used in the last sentence refers to an event taken place inside the text.

\section{Interpretation and Explanation}

The present excerpt is the discursive representation of the evils in the Pashtun society. The producer of the story constructs the main evils and problems of the society depicted in the discourse. These evils are gender discrimination, inequality, dominance, and power.

The word "strong" in the very first sentence is linguistically and grammatically an adjective that discursively shows manpower and dominance. The writer has depicted men as strong either bodily or socially while women are shown as weak and mild. That means that the Pashtun society gives no importance to women and considers them as slaves and that is the main cause of their subjugation and discrimination between man and woman. The word's lexicographical meaning is physical power and ability to do something but it has some other meanings too in different contexts such as one who has intellectual or moral power, or who has great resources, or one who is superior. But, here, in this text (discourse) it can be taken as one who is superior to his kind and dominant in the social context of the story. The expression "He always...her" in the second sentence linguistically embodies the unjust treatment of men with women either they are their wives or having no relation with them. As a whole, women are treated as inhuman or animals who have no right to be treated equally as men. The word "beat" represents linguistically an inhuman treatment and brutality of men of the society. The word socially means to give physical punishment by slapping or punching or hitting someone with a stick. This shows the maltreatment and distinctive attitude of men towards women in society.

Again, the reputation of the collocation "I hate" in sentence 3 discursively depicts the digestive approach towards the evil pervaded in the very veins of the society. The word "hate" constructs one's harassment from something unbearable and maltreatment. The author of the text discursively shows the hatred towards the evil which made society hell for the oppressed. Similarly, the last sentence of the passage also condemns the maltreatment of men towards women. The word "weak" is used here, as a personification for the women because it's the society that made them weak and helpless while men are considered strong and powerful.

\section{Ideological Construction of Power and Powerlessness}

The selected text is the ideological representation of gaining power through becoming a Badmash. The discourse constructs the feelings of hatred and resentment towards the society where the basic source of power is considered to be a bad and dreadful person. The society is shown as in control of such persons who have strength, power, and are bad. In such a society one has to become a badmash which is the source of power and control, and which is the solution to all problems faced in society.

\section{Extract 2}

"He had his own idea-one idea only- to become a badmash, the solution to all problems in the world. Then he would get all those things which he could not get before." (Badmash, p-167).

\section{Description}

The text has its relational, experiential, grammatical, and structural values. The conversation is formal which expresses one's personal feelings and ideas. The text is analyzed under questions 1, 2, 5, 6, and 8 of Fairclough's (1989, p-110-112) framework. The ideologically weighted words, phrases, clauses, and expressions are the word "idea", the word "badmash", the expression "the solution of ... in the world" and the expression "get all those things". There are only two sentences in the extract. The first sentence is a complex one having its main and subordinate clauses with an explanatory phrase "one idea only". The second sentence is perhaps a conditional compound sentence consists of two parts connected by the conjunction "which".

Pronouns having grammatical and relational values are used exclusively for only one individual i.e. the third person pronoun "he" occurred one time in the first sentence and two times in 
the second sentence, the possessive case pronoun "his" in a sentence first. The demonstrative pronoun "those" is used for referring to things inside or outside the text. The agency in the use of the word "things" in the second sentence is unclear. The passage also has some ideologically contested words such as the word "badmash" and the word "solution". Both these words are in contrast to each other but the text producer points that to become a badmash is the only solution to all problems.

\section{Interpretation and Explanation}

The passage discursively represents power and powerlessness in the society depicted in the discourse. The society has been depicted as savages living society that brutally treat the weak creatures i.e. women. Where the main source of power is considered to be strong, bad, and wicked. The story constructs a society in which there are no human values and morals to live a good life. Those who live good lives are considered weak and dominated, and suppressed. The idea of becoming "badmash" is the discursive representation of power gaining and dominating others through it. This makes the ideological construction of powerfulness and powerlessness of the dominant and dominated respectively.

The text producer represented the inner psyche of society. He wants to shed light on all the evils in the society in which he breathes because making people aware of some evil can be considered as the first step to get rid of it. The expression "... to become a badmash, the solution to all problems in the world" represents the diverse nature of society. Almost in every society, becoming a badmash (bad man) is considered unlawful and unjust but here, in this context, it can be taken as good for one's survival and the solution of all problems. And it can be proved for getting all the privileges and things of which one has been deprived for a long time. The expression "Then he would get... get before" discursively shows one's embarrassment of the situations and conditions of a society. Conclusion

Fairclough's framework of CDA is the best tool for analyzing a piece of text (discourse). The critical analysis of the text has been conducted through his approach to CDA using his Three Dimensional Model (TDM). The study can be proved useful for other researchers and scholars who conduct their research through Faiclough's framework of CDA. The study found certain themes from the analysis of the short story under investigation. These themes are in equal power relations, gender discrimination, powerlessness, and dominance. The text producer has constructed all these themes through using various linguistic choices which the researcher explored with the help of Fairclough's framework.

Thus the analysis shows that Hamid Khan has depicted a realistic portrait of one of the most crucial aspects of Pashtun society. He has sided with the marginalized of society. The story compels the reader to ponder over the hardships faced by women; it advocates, indirectly, reformation of the society, as without realizing the rights of women, a society cannot progress rather it goes down. The paper shall provide a guideline for future researchers to conduct their studies on local literature both written in English and their mother tongue.

\section{References}

Anderson. J., and Gerbing, D. (1988). Structural equation modeling in practice: A review and recommended two-step approach, Psychological Bulletin, 103(3): 411-423

Awan, A. G., and Yahya, M (n.d.). Critical Discourse Analysis of Ahmad Ali's Twilight in Delhi. Sci. Int. (Lahore), 28 (2): 2047-2052

Brown, V. (1994). Adam Smith's discourse: canonicity, commerce, and conscience. London: Routledge. www.ebooksclub.org.

Cook, G, (1990), 'Discourse' Oxford: Oxford University Press

Fairclough, N., and Wodak, R. (1997). Critical discourse analysis, in T. van Dijk (ed.) Discourse as Social Interaction, London: Sage.

Fairclough, Norman (1989). Language and Power. London: Longman, print

Hajiyeva, Mahira (2016) "Pakistani English Literature in Multicultural Context". Journal of Research (Humanities): 133-144. http://www.pu.edu.pk. Retrieved 08/11/2020.

Haliday, Michael Alexander Kirkwood, (1978). Language as Social Semiotics: The Social Interpretation of Language and Meaning, London, Edward Arnold (Publishers) Ltd

Khan, Abdul Karim (2020), 'Parallelism of Words and their Socio-cultural Implications in Hamid Khan's Velvet of Loss'. Sir Syed Journal of Education \& Social Research, 3 (3): 169-175 
Khan, Abdul Karim and Zahir Jang, Dr. (2020), 'Exploring Socio-cultural Issues through CodeSwitching in the Poetry of Hamid Khan', Sir Syed Journal of Education \& Social Research. 3(1): $67-73$

Khan, Hamid. (1982). "Badmash” The Journal of the English Literary Club. Department of English, University of Peshawar, Pakistan. Issue 1982 - 1983: 163-168

Mirzaee, Sepideh \& Hamidi, Hadi 2012.Critical Discourse Analysis and Fairclough's Model. ELT Voices-India. 2 (5): 182-19

Parker, Ian (1992), Discourse Dynamics: Routledge. London and New York

Van Dijk, T.A. (1998). Critical Discourse Analysis. http://www.hum.una.nl/teun.cda.htm Retrieved $05 / 09 / 2020$ 